\title{
CONSIDERATIONS ON THE BEST INTERESTS OF THE CHILD AS A PRINCIPLE OF EXERCISING PARENTAL AUTHORITY
}

\author{
Cosmina Flavia Bobar \\ „Vasile Goldiș” Western University of Arad \\ „Lucian Blaga” University of Sibiu, Faculty of Law, PhD Candidate \\ E-mail: bobarcosmina@yahoo.com
}

(Received September 2016; Accepted November 2016)

\begin{abstract}
The principle of the best interests of the child is the basis for international or national normative documents adopted after the 1989 UN Convention on the Rights of the Child. They enshrine the prevalence of this principle in any decision that must be made with regard to the child, and regardless of its author.

In the matter of parental authority, the Romanian Civil Code subordinates parental rights and duties to this principle, placing the interests of the child above the interests of parents. This study presents such aspects as referring to the principle of the best interests of the child, including from a historical perspective, while also emphasising concern in the doctrine for defining but also establishing criteria to appraise the best interests of the child, prior to the amendment of Law no. 272/2004 on the protection and promotion of children's rights.
\end{abstract}

\section{Introduction}

The best interests [1] of the child is one of the fundamental principles of parental authority, and its regulation has constituted a „legal guarantee”, which, on the one hand, has the role of preventing parents from derailing parental protection from its intended purpose and using it to fulfil their own interests, and on the other hand, provides effective protection against any abuses committed by parents [2].

In art. 263 of the Romanian Civil Code [3], the legislator indicates the binding character of this principle. Thus, para. (1) stipulates that the best interests of the child must be given precedence whenever a measure is taken concerning the child and regardless of the author of that measure, while noting that the term „child" [4] signifies ,the person which has not reached the age of 18 and has not acquired full capacity of exercise, under the law" [para. (5)].

The term ,author" primarily refers to parents, who are the first to be called upon to respect the best interests of the child, as evidenced by the provisions of art. 5 para. (2) of Law no. 272/2004 on the protection and promotion of children's rights [5]. Thus: „Responsibility for bringing up and securing the development of the child is incumbent first on the parents, who must exercise their rights and fulfil their obligations towards the child by giving precedence to its best interests." Likewise, in art. 483 para. (2) of the Romanian Civil Code, the legislator establishes that parents shall only exercise parental authority in the best interests of the child [6]. In 
the same vein are the provisions of art. 2 para. (3) of Law no. 272/2004. Also, according to the same article, the ,author" can be another legal representative of the child, or any other person in whose care the child was entrusted.

Not least, the status of ,author” can also be assigned to courts of justice who must subordinate their decisions to the best interest of the child. Regarding this, de lege lata, in the case where there are disagreements between the parents about the exercise of parental authority, the court, after hearing both parents, shall decide after considering the best interests of the child [art. 36 para. (8) of Law no. 272/2004].

In conclusion, this principle is enforceable against parents or any other persons who act in loco parentis, when exercising parental authority, and also to the state, when exercising its functions in matters referring to the child or which involve children.

As regards the child, as a beneficiary of the principle of best interests, it should be said that no domestic or international normative act regarding children's rights makes any discrimination between them. In order words, the best interests of the child prevail whether we are talking about children born in or out of wedlock, or adopted children. Referring to this aspect, particularly art. 7 of Law no. 272/2004 establishes that: „The rights stipulated by this law are guaranteed to all children without any discrimination, regardless of race, colour, sex, language, religion, political or other opinion, nationality, ethnicity or social origin, material status, the degree of type of any deficiency, status upon birth or acquired, difficulties in formation and development or of any other kind of the child, parents or any other legal representatives or of any other distinction".

\section{Evolution of legal regulations regarding the best interests of the child}

The principle of the best interests of the child was first formulated in 1924, in the Declaration of the Rights of the Child, adopted by the League of Nations. This Declaration was practically the first document dealing with children's rights to appear internationally and underlined that "mankind owes to the Child the best that it has to give".

The following international document to be aimed at the same rights appeared in 1959. This document was also called Declaration of the Rights of the Child [7], and comprised over ten Principles regarding children's rights. Thus, the text of Principle 2 of this Declaration stipulated that "The child shall enjoy special protection, and shall be given opportunities and facilities, by law and by other means, to enable him to develop physically, mentally, morally, spiritually and socially in a healthy and normal manner and in conditions of freedom and dignity. In the enactment of laws for this purpose, the best interests of the child shall be the paramount consideration." 
Bobar C.F (2016)

Considerations on the best interests of the child as a principle of exercising parental authority

Thus, if up until the beginning of the $20^{\text {th }}$ century, children were seen as an extension of their parents, the development of such international legislative documents proves, on the one hand, that the dominant mentality of those times underwent a change, with the recognition of the fact that children have their own rights, different from those of the parents, and on the other hand, a concern for providing special protection to children and for their harmonious development. Relevant in this regard is Recommendation 874 (1979) of the Parliamentary Assembly of the Council of Europe [8], which states in its first principle the following: "Children must no longer be considered as parents' property, but must be recognised as individuals with their own rights and needs".

The 1959 Declaration of the Rights of the Child was the basis for the adoption of the UN Convention on the Rights of the Child [9] in 1989. This Convention took the principle of the best interests of the child from the above-mentioned Declaration, and introduced it in the contents of several articles [10]. In particular, we shall make note of art. 3, para. 1 of the Convention, which enshrines the principle of promoting and respecting the best interests of the child, so that: "In all actions concerning children, whether undertaken by public or private social welfare institutions, courts of law, administrative authorities or legislative bodies, the best interests of the child shall be a primary consideration." In other words, in any decision regarding the child which can influence its life, health or development, priority must be given to the best interests of the child, regardless of the person or institution which made those decisions. In the same vein was expressed Recommendation R (84) 4 of the Committee of Ministers of the Council of Europe on Parental Responsibilities [11], which, under Principle 2, stipulated that: „Any decision of the competent authority concerning the attribution of parental responsibilities or the way in which these responsibilities are exercised should be based primarily on the interests of the child."

The principle of the best interests of the child is the basis for national or international normative acts, which deal with the protection of the child and which were adopted after the Convention. Thus, at European level, numerous binding or recommending normative acts were adopted around it in the area of family law and children's rights. In this sense, we evoke the Recommendation of the Commission of European Family Law (CEFL) [12], which at Principle 3:3, under the marginal name „Best Interests of the Child”, stipulates that in all aspects regarding parental authority, the best interests of the child should prevail. Another telling example is the Convention on Contact concerning Children [13], where the phrase "best interests of the child" is featured in various articles regarding children's rights [14]. In domestic law, the principle of the best interests of the child was first enshrined by the Family Code [15]. Thus, art. 97 para. (2) of the Romanian Family Code stipulated that parents ,shall exercise their parental rights only in the best interests of children". In the same vein were the provisions of art. 1 para. (5) of the 
Romanian Family Code, according to which "Parental rights shall be exercised only in the interests of children". The need to reform the child protection system in post-1989 Romania led to the development of a National Strategy for the Protection of the Child [16] which proposed, among others, bringing the Romanian child protection system in line with the standards of the Convention [17]. To this end, a legislative package was adopted to regulate the protection of children's rights, in accordance with the Convention. In this sense, it is worth mentioning Law no. 272/2004 on the protection and promotion of children's rights; Law no. 273/2004 regarding the legal regime of adoption [18]; Law no. 274/2004 on the establishment, organisation and management of the Romanian Office for Adoptions [19]; Law no. 275/2004 for the amendment of GEO no. 12/2001 on the establishment of the National Authority for Child Rights Protection and Adoption [20].

At present, the Romanian Civil Code enshrines the principle of the best interests of the child in numerous of its provisions in Book II entitled „On family”.

\section{Concept and content}

The phrase best interests [21] of the child is not defined in domestic or international normative acts as it has a complex content [22] and, consequently, hard to establish particularly due to the multiple situations in which a child can be found at a given moment. The task of establishing this content falls, in this case, with the judge, when settling clams referring to children, to competent authorities or other authorised persons [23]. The complex character of this principle is translated in its large scope of action in the area of respect for and promotion of children's rights. For example, we find it regulated in connection with the rights and obligations of parents toward their children; the exercise of parental authority; the establishment of residence; the conclusion of an individual contract of employment, etc. The best interests of the child are an abstract concept [24] since achieving it involved the recognition and guarantee of fundamental rights of the child, and in order to guarantee the best interests of the child, one must consider its special needs, which are due to its age and degree of maturity.

In the silence of the law, in Romanian doctrine there has always been a concern for defining the phrase "best interests of the child". Thus, some authors have appraised the best interests of the child to signify a superior social interest and a personal interest [25]. Concretely speaking, it was asserted that, according to the superior social interests, parents have the obligation to raise and educate their child in accordance with the general rules and principles established by society, and according to the personal interests, parents are obliged to take care of its health and physical development, education and professional training, considering the characteristics and needs of the child. 
Any measure that must be taken in connection with the child should be based on the idea that the best interests of the child must be protected. However, in the application of the principle, one cannot annul other rights of the child that are enshrined by Law no. 272/2004 and the Convention.

The best interests of the child must always be appreciated within the limits of the law, in the sense that they cannot be achieved while infringing some legal provisions and giving the justification that this is required by the best interests of the child. [26] To be more specific, one cannot accept a solution which, while benefitting the child, infringes a legal provision.

Before the amendment and supplementation of Law no. 272/2004 by Law no. 257/2013 [27], Romanian jurisprudence established a few criteria for appraising the best interests of the child, for example: the age of the child, the conduct of the parents, their financial status, their health state, etc.) [28].

Regarding the criteria for appraising the best interests of the child, the manual entitled „The Role of Judges and Prosecutors in the Protection and Promotion of the Rights of the Child" edited by the now defunct National Authority for the Protection of Children's Rights [29], stated that objective criteria must be used by the judge, so as to avoid, making decision on the sole basis of sentiment or personal convictions. In the jurisprudence of Quebec province [30], the principle of the best interests of the child, known as "le meilleur intérêt de l'enfant" is appraised according to the following criteria, namely: the needs of the child; parental capacity to respond to the needs of the child; the affective relationship between the child and its parents; the affective relationship between the child and family members; the child's stability; the child's psychosocial environment; the physical and mental health of the child and of the person who claims the right of hosting; the real availability of parents; the parents' lifestyle, if this has a direct impact on the child; not separating siblings; the child's wishes; willingness to foster the relationship with the other parent.

In the domestic law of Romania, with the amendment and supplementation of Law no. 272/2004 by Law no. 257/2013, the criteria for determining the best interests of the child were established, for the first time, in the text of art. 2 para. (6), as follows: a) needs for physical and psychological development, education and health, security and stability and belonging to a family; b) the child's opinion, depending on age and degree of maturity; c) the child's history, with particular consideration for situations of abuse, neglect, exploitation or any other form of violence against the child, as well as potential risk situations that may occur in the future; d) the capacity of parents or persons who seek to raise and care for the child to respond to the child's actual needs; e) maintaining personal relations with persons towards whom the child has developed attachments. 
Considerations on the best interests of the child as a principle of exercising parental authority

The best interests of the child govern the matters of adoption, together with four other fundamental principles [31], while also representing, the purpose of its approval [32]. With reference to this last aspect, art. 480 of the Romanian Civil Code specifies under para. (2) that adoption concluded for any other purpose than that of protecting the best interests of the child is fictive, thus entailing absolute nullity [para. (1) of the Romanian Civil Code].

\section{Conclusions}

The best interests of the child is a concept which the legislator has avoided defining, due to its evident complexity. To attempt a definition of this concept presupposes comprising within it all important aspects that must be considered when investigating the child welfare. For this reason, its content must be established in relation to each child, depending on the age, physical and psychological development, health state, background, etc. Thus, the best interests of the child are not general or abstract, but concrete and individual, and they differ from one child to another.

\section{Notes}

[1] In legal literature the legislator's use of the singular form for the concept of interest has been criticised, and the plural use has been brought forward for this notion (see $\mathrm{T}$. Bodoaşcă, Unele aspecte critice referitoare la necorelarea unor dispoziții din Legea nr. 272/2004 privind protecția și promovarea drepturilor copilului cu anumite norme din Legea $n r .273 / 2004$ privind regimul juridic al adopției, in „Dreptul” no. 5/2005, p. 60).

[2] See A. Ionașcu, M. Mureșan, M. N. Costin, V. Ursa, Filiația şi ocrotirea minorilor, Editura Dacia, Cluj- Napoca, 1980, p. 174.

[3] Law no. 287/2009 on the Romanian Civil Code, published in the Official Gazette of Romania no. 511 of 24 July 2009, and then republished in the Official Gazette of Romania no. 505 of 15 July 2011, as subsequently amended and supplemented. Brevitatis causa, throughout the paper, references to Law no. 287/2009 on the Romanian Civil Code shall hereinafter be made using the expression „Romanian Civil Code”.

[4] Regarding the legal meaning of the term "child", see T. Bodoașcă, Opinii privind semnificația termenului “copil”, in „Dreptul” no. 6/2014, p. 126.

[5] Law no. 272/2004 on the protection and promotion of children rights was published in the Official Gazette of Romania, Part I, no. 557 of 23 June 2004, and then republished in the Official Gazette of Romania, Part I, no. 159 of 5 March 2014. Brevitatis causa, we shall hereinafter refer to this law by using the abbreviation „Law no. 272/2004”.

[6] See also Judgement of 7 August 1996, § 78, in the case Johansen v. Norway, from the ECHR jurisprudence, where it is shown that: "In achieving this exercise of fair balance, the Court shall give particular importance to the best interests of the child, which, according to its nature and severity, shall override the interests $f$ the parents", taken from the website http://hudoc.echr.coe.int/sites/eng/Pages/search.

[7] The 1959 Declaration of the Rights of Child was proclaimed by Resolution 1386 (XIV) of the UN General Assembly, of 20 November 1959, and an extension to the Universal 


\section{JOURNAL OF LEGAL STUDIES}

"Vasile Goldiș" Western University of Arad

Bobar C.F (2016)

Considerations on the best interests of the child as a principle of exercising parental authority

Declaration of Human Rights. It is available at http://salvaticopiii.ro/ upload/p000600010000_Declaratia\%20drepturilor \%20copilului\%201959.pdf.

[8] Recommendation 874 (1979) of the Parliamentary Assembly of the Council of Europe was adopted on 4 October 1979. Available in Romanian at https://drive.google.com/file/d/1FLbp

BPcHewf_srr1xPDUrxjgNpBG3CILLr8dMwigT89A0zbfPhywwOc6mYk/view.

[9] Adopted by the United Nations General Assembly on 29 November 1989, and entered into force on 2 September 1990. Romania ratified the Convention by Law no. 18/1990, published in the Official Gazette of Romania, Part I, no. 109 of 28 September 1990 and republished in the Official Gazette of Romania, Part I, no. 314 of 13 June 2001. Brevitatis causa, the UN Convention on the Rights of the Child shall hereinafter be referred to in the paper under the abbreviation „Convention”.

[10] See: Art. 9, Art. 18, Art. 20, Art. 21, Art. 37, Art. 40 of the Convention.

[11] Recommendation R (84) 4 of the Committee of Ministers of the Council of Europe on parental responsibilities was adopted by the Committee of Ministers on 28 February 1984, on the $367^{\text {th }}$ reunion of ministerial delegates. Available on http://blog.arpcc.ro/2012/05/recomandarea-nr-r-84-4-comitetului.html.

[12] Available in Romanian at https://drive.google.com/file/d/0B-iOqOKLc35PZ mZjYmZmZjEtMGVmZS00ZTM0LWFjZGYtZWZjMzgyMjQyNjRh/view?hl=en_.

[13] The Convention on Contact concerning Children was adopted at Strasbourg on 15 May 2003 and ratified by Romania by Law no. 87 of 3 April 2007 (published in the Official Gazette of Romania, Part I, no. 257 of 17 April 2007).

[14] See: Art. 4, Art. 5, Art. 6, Art. 8 of the Convention on Contact concerning Children.

[15] The Romanian Family Code was adopted by Law no. 4/1953, published in the Official Gazette of Romania, Part I, no. 1 of 4 January 1954, and then republished in the Official Gazette of Romania, Part I, no. 13 of 18 April 1956, being subsequently amended and supplemented, then expressly abrogated by art. 230 let. m) of Law no 71/2011 for the implementation of Law no. 287/2009 on the Romanian Civil Code (published in the Official Gazette of Romania, Part I, no. 409 of 10 June 2011).

[16] The National Strategy for the Protection of the Child was enforced by GD no. $260 / 2000$ on the approval of national programs concerning the protection of the rights of children in difficulty, published in the Official Gazette of Romania, Part I, no. 171 of 21 April 2000, as subsequently amended.

[17] For details, see M. A. Oprescu, Ocrotirea părintească, Editura Hamangiu, București, 2010, p. 21-22.

[18] Law no. 273/2004 was published in the Official Gazette of Romania, Part I, no. 557 of 23 June 2004, and then republished in Official Gazette of Romania, Part I no. 259 of 19 April 2012, being subsequently amended and supplemented.

[19] Law no. 274/2004 was published in Official Gazette of Romania, Part I, no. 557 of 23 June 2004, and then republished in Official Gazette of Romania, Part I no. 108 of 17 February 2010.

[20] Law no. 275/2004 on the amendment of GEO no. 12/2001 for the establishment of the National Authority for Child Rights Protection and Adoption was published in the Official Gazette of Romania, Part I, no. 557 of 23 June 2004. 
Considerations on the best interests of the child as a principle of exercising parental authority

[21] The term "interest" must be understood in the sense of advantage or benefit (in this sense, see Dicționarul explicativ al limbii române (Dex), ediție revăzută și adăugită, Academia Română, Institutul de Lingvistică "Iorgu Iordan- Al. Rosetti", Editura Univers Enciclopedic, București, 2016, p. 563.

[22] See C. Ap. București, $3^{\text {rd }}$ Civil Section for Cases involving Minors and Family Matters, Dec. 1248/13.10.2011. no. Available at http://www.jurisprudenta.com/jurisprudenta/speta-180188d/.

[23] See A. Drăghici, Protecția juridică a drepturilor copilului, Editura Universul Juridic, București, 2013, p. 32-33.

[24] See Al. Bacaci, V.- C. Dumitrache, C. C. Hageanu, Dreptul familiei, ediția 7, Editura C. H. Beck, București, 2012, p. 308.

[25] See, for example, C. C. Hageanu, Dreptul familiei și actele de stare civilă, Editura Hamangiu, București, 2012, p. 13. For another definition, similar in content, see V. D. Zlătescu, Dreptul familiei și ocrotirea minorilor (Contribuție la studiul unor concepte și instituții juridice, dedicată Anului Internațional al Copilului), in „Revista română de drept” no. 9/1979, p. 6-7.

[26] In this sense, see I. P. Filipescu, Noțiunea de interes al minorului și importanța determinării lui, în „Revista română de drept” no. 2/1988, p. 25.

[27] Law no. 257/2013 was published in the Official Gazette of Romania, Part I no. 607 of 30 September 2013, being available at

http://www.dreptonline.ro/legislatie/legea_257_2013_modificare_legea_272_2004_protecti a_promovarea_drepturilor_copilului.php.

[28] See, for example, Jud. sectorului 2 București, S. civ., Sent. nr. 10243/2012 în G. C. Frențiu, Dreptul familiei. Practică judiciară conform noului Cod civil. Jurisprudență C.E.D.O., Editura Hamangiu, 2013, p. 123.

[29] The National Authority for the Protection of Children's Rights (ANDPC) was established in 2001 and then dissolved in 2006, its duties being taken over by the National Authority for the Protection of the Family and Children's Rights (ANPFDC).

[30] See Judgment of 3 December 2015 (Droit de la famille-153073), taken from http://ccq.lexum.com/.

[31] In this sense, art. 452 of the Civil Code stipulates that "Adoption is cumulatively subject to the following principles: a) the best interests of the child; b) the need to ensure that the child is raised and educated in a family; c) the continuity of upbringing and education of the child, considering its ethnic, linguistic, religious and cultural origin; d) expediency in fulfilling any acts referring to the adoption procedure".

[32] In the doctrine, it has been suggested that the legislator should opt for one of the two legal roles of the principle of the best interests of the child (in this sense, see T. Bodoaşcă, A. Drăghici, I. Puie, I. Maftei, Dreptul familiei, ediția a II- a, Editura Universul Juridic, București, 2013, p. 398).

\section{References}

1. Bodoașcă T., Unele aspecte critice referitoare la necorelarea unor dispoziții din Legea nr. 272/2004 privind protecția și promovarea drepturilor copilului cu 


\section{JOURNAL OF LEGAL STUDIES}

"Vasile Goldiș" Western University of Arad

Bobar C.F (2016)

Considerations on the best interests of the child as a principle of exercising parental authority anumite norme din Legea nr. 273/2004 privind regimul juridic al adopției, in "Dreptul" no. 5/2005

2. Bodoaşcă T., Drăghici A., Puie I., Maftei I., Dreptul familiei, ediția a II- a, Editura Universul Juridic, București, 2013.

3. Ionașcu A., Mureșan M., Costin M. N., Ursa V., Filiația și ocrotirea minorilor, Editura Dacia, Cluj- Napoca, 1980

4. Oprescu M. A., Ocrotirea părintească, Editura Hamangiu, București, 2010

5. Dicționarul explicativ al limbii române (Dex), ediție revăzută și adăugită, Academia Română, Institutul de Lingvistică "Iorgu Iordan- Al. Rosetti", Editura Univers Enciclopedic, București, 2016.

6. Drăghici A., Protecția juridică a drepturilor copilului, Editura Universul Juridic, București, 2013.

7. Bacaci Al., Dumitrache V.- C., Hageanu C. C., Dreptul familiei, ediţia 7, Editura C. H. Beck, București, 201.

8. Hageanu C. C., Dreptul familiei și actele de stare civilă, Editura Hamangiu, București, 2012

9. Zlătescu V. D., Dreptul familiei și ocrotirea minorilor (Contribuție la studiul unor concepte și instituții juridice, dedicată Anului Internațional al Copilului), in "Revista română de drept" no. 9/1979.

10. Filipescu I. P., Noțiunea de interes al minorului și importanța determinării lui, în „Revista română de drept” no. 2/1988.

11. Frențiu G. C., Dreptul familiei. Practică judiciară conform noului Cod civil. Jurisprudență C.E.D.O., Editura Hamangiu, 2013.

12. Law no. $272 / 2004$ on the protection and promotion of children's rights

\section{Websites:}

1. http://ccq.lexum.com/.

2. http://www.dreptonline.ro/legislatie/

3. http://www.jurisprudenta.com/

4. http://hudoc.echr.coe.int/sites/eng/Pages/search.

5. http://salvaticopiii.ro/

6. http://blog.arpcc.ro/

7. www.legalis.ro 